\title{
Antimicrobial Efficacy of Various Concentrations of Bamboo Salt against Enterococcus faecalis and Candida albicans: An in vitro Study
}

\author{
${ }^{1}$ Santosh Kumar P, ${ }^{2}$ Vidhya S, ${ }^{3}$ Mahalaxmi S
}

\begin{abstract}
Sodium hypochlorite $(\mathrm{NaOCl})$ remains the gold standard against which any new endodontic irrigant is compared. But, its inadvertent extrusion beyond the confines of the root canal can be caustic to vital periapical or periodontal tissues. There has been an increase in the use of herbal medicines as irrigants over the last two decades. Bamboo salt is a Korean folk medicine, which shows promising antimicrobial, antioxidant, and anti-inflammatory properties. The aim of this in vitro study was to comparatively evaluate the effectiveness of 1,3 , and $5 \%$ bamboo salt against Enterococcus faecalis and Candida albicans using agar diffusion test; $4 \% \mathrm{NaOCl}$ was used as control. The experiment was performed in triplicate and the zone of inhibition (ZOI) was measured. The results of the present study showed that $4 \% \mathrm{NaOCl}$ and $5 \%$ bamboo salt showed significantly higher mean ZOI than the other groups against E. faecalis; $4 \% \mathrm{NaOCl}$ showed significantly higher mean ZOI than the other groups against $C$. albicans, followed by 5 and $3 \%$ bamboo salt. Hence, it can be concluded that $4 \% \mathrm{NaOCl}$ proved to be the most effective antimicrobial against both the species; $5 \%$ bamboo salt was as effective as $4 \% \mathrm{NaOCl}$ against $E$. faecalis, but significantly less effective against $C$. albicans.
\end{abstract}

Keywords: Antimicrobial, Bamboo salt, Candida albicans, Endodontic irrigants, Enterococcus faecalis, Sodium hypochlorite.

How to cite this article: Santosh KumarP, Vidhya S, Mahalaxmi S. Antimicrobial Efficacy of Various Concentrations of Bamboo Salt against Enterococcus faecalis and Candida albicans: An in vitro Study. J Oper Dent Endod 2017;2(2):65-68.

Source of support: Nil

Conflict of interest: None

\section{INTRODUCTION}

Bacteria play a pivotal role in the development of pulpal and periapical lesions. ${ }^{1,2}$ Endodontic infection involves multiple bacterial species, with E. faecalis being the most commonly associated strain in persistent endodontic infection and failed endodontic treatment. ${ }^{3}$

\footnotetext{
${ }^{1}$ Postgraduate Student, ${ }^{2}$ Reader, ${ }^{3}$ Professor and Head

${ }^{1-3}$ Department of Conservative Dentistry and Endodontics, SRM Dental College, Chennai, Tamil Nadu, India

Corresponding Author: Vidhya S, Reader, Department of Conservative Dentistry and Endodontics, SRM Dental College Chennai, Tamil Nadu, India, Phone: +9104422490526, e-mail: drvidhyas@yahoo.co.in
}

E. faecalis, a gram-positive, facultative anaerobic cocci can withstand very harsh intracanal conditions, such as an extreme $\mathrm{pH}$ of 9.6 and high temperatures of about $60^{\circ} \mathrm{C}$. It possesses several other virulence factors, which make it the star survivor of the root canal. ${ }^{5}$ Previous studies have shown that $<1 \%$ of root canal flora in persistent cases of apical periodontitis is composed of yeast. ${ }^{6}$ Though yeasts comprise a smaller proportion, their eradication is challenging as they are resistant to most of the currently available antimicrobials. Among the yeasts, C. albicans is the most commonly detected species in infected root canals. ${ }^{6,7}$ Chandra et $\mathrm{al}^{7}$ observed that C. albicans was more resistant to irrigating solutions in the presence of a smear layer.

The main goal of endodontic therapy is to reestablish a healthy status for the tooth by eliminating microbes and their by-products. ${ }^{8}$ Instrumentation of the root canal results in reduction of microbes to an extent but leaves many areas unaffected. Hence, the use of an irrigant becomes an indispensable part of cleaning and shaping of the root canal. ${ }^{9}$ Most commonly used irrigants are $\mathrm{NaOCl}$ and chlorhexidine. Various studies have proven their effectiveness against root canal flora, including E. faecalis and C. albicans. ${ }^{8}$

The irrigants used in contemporary dental practice are associated with some kind of allergic or toxic reactions. ${ }^{10}$ Sodium hypochlorite is reported to cause adverse reactions like chemical burns and necrosis of the periapical tissues. ${ }^{11-13}$ Mohammadi and Abbott ${ }^{14}$ reported that chlorhexidine causes allergic reactions like desquamative gingivitis and discoloration of teeth and gums. Hence there is a constant quest for an ideal root canal irrigant with no or minimal adverse effect.

Various natural products with a wide range of therapeutic properties have been experimented as endodontic irrigants and medicaments. Azadirachta indica, aloe vera, and garlic are some of them. ${ }^{15,16}$ Bamboo salt is one such product, which is derived by burning natural salt obtained from yellow sea in bamboo sticks using pinewood as fuel. The salt from yellow sea is rich in mineral content. It is not only used as taste enhancer in Korean cuisine but is also reported to have antimicrobial, antioxidant, and anti-inflammatory properties. ${ }^{17,18}$ Shin et $\mathrm{al}^{19}$ and Moon et $\mathrm{al}^{20}$ have reported that bamboo salt is 
effective against $S$. mutans and $S$. enteritidis respectively. However, its efficacy against endodontic pathogens is not yet known. Hence, the aim of this in vitro study was to evaluate the effectiveness of three different concentrations of bamboo salt against E. faecalis and C. albicans using agar diffusion test.

\section{MATERIALS AND METHODS}

\section{Preparation of Microbial Inoculum}

Pure cultures of test strain E. faecalis ATCC 29212 and C. albicans ATCC 10231 were grown in Mueller-Hinton broth (Himedia Laboratories, Mumbai, India) and Sabouraud dextrose broth (Himedia Laboratories, Mumbai, India) respectively. The microbial load was standardized to an optical density of approximately $0.5 \times 10^{8}$ colony forming units (CFU) $/ \mathrm{mL}$ for E. faecalis and $1.5 \times 10^{8} \mathrm{CFU} / \mathrm{mL}$ for $C$. albicans by comparing its turbidity to a McFarland 0.5 scale.

\section{Preparation of Solutions and Grouping}

In a sterile beaker, 1,3 , and $5 \%$ bamboo salt solutions were prepared by mixing 1, 3, and $5 \mathrm{gm}$ of bamboo salt (Koreasalt Co. Ltd., Gyeongsangnam, Korea) in 100 mL of distilled water respectively. The sterility check was done for the solutions. The experimental groups were as follows: Group I - 4\% NaOCl (Prime Dental Products Pvt. Ltd., Mumbai, India), group II - 1\% bamboo salt solution, group III - 3\% bamboo salt solution, and group IV - 5\% bamboo salt solution.

\section{Agar Diffusion Test}

In agar plates $8 \mathrm{~mm}$ diameter wells were punched. Three such wells were used for each group. Mueller-Hinton agar (Himedia Laboratories, Mumbai, India) was selected for E. faecalis and Sabouraud dextrose agar (Himedia Laboratories, Mumbai, India) for C. albicans. The microbial streaking was done on the respective culture plates. In each well, $100 \mu \mathrm{L}$ volume of the experimental solution was deposited. The entire procedure was carried out in a biosafety cabinet. The plates thus prepared were incubated at $37^{\circ} \mathrm{C}$ for 24 hours in an incubator. The ZOI was measured and expressed in millimeters. The mean of the three ZOIs was calculated for each group. Statistical analysis was done by one-way analysis of variance and Kruskal-Wallis test $(\mathrm{p}<0.05)$.

\section{RESULTS}

The mean ZOI of the experimental groups against E. faecalis and C. albicans is given in Table 1. Group I (4\% $\mathrm{NaOCl}$ ) showed the highest ZOI followed by group IV ( $5 \%$ bamboo salt), group III ( $3 \%$ bamboo salt), and group II ( $1 \%$ bamboo salt) against both E. faecalis and C. albicans.
Table 1: The ZOI (mean \pm standard deviation) of the experimental agents against $E$. faecalis and $C$. albicans

\begin{tabular}{lll}
\hline Groups & E. faecalis & C. albican \\
\hline I & $17.30 \pm 0.503^{\mathrm{a}}$ & $20.20 \pm 0.721^{\mathrm{a}}$ \\
II & $11.67 \pm 0.577^{\mathrm{b}}$ & $10.33 \pm 1.528^{\mathrm{c}}$ \\
III & $13.33 \pm 0.577^{\mathrm{b}}$ & $13.80 \pm 1.058^{\mathrm{b}}$ \\
IV & $16.33 \pm 1.155^{\mathrm{a}}$ & $16.33 \pm 1.155^{\mathrm{b}}$ \\
\hline
\end{tabular}

Under each microbe, different superscript letters $(a, b, c)$ indicate statistically significant difference between the groups $(p<0.05)$.

Against E. faecalis, groups I and IV showed significantly higher mean ZOI than the other groups $(\mathrm{p}<0.05)$. There was no significant difference between groups II and III against E. faecalis ( $\mathrm{p}>0.05)$. Against $C$. albicans, group I showed significantly higher ZOI than the other groups. Groups IV and III showed significantly higher ZOI than group II, but lesser than group I $(\mathrm{p}<0.05)$.

\section{DISCUSSION}

Enterococcus faecalis is the most commonly found bacteria in persistent periradicular lesions and root filled teeth. ${ }^{3}$ The myriad virulence factors associated with E. faecalis make it resistant to most of the currently used antimicrobial agents. ${ }^{21}$ It possesses lytic enzymes like cytolysin, which lyse other bacteria. It adheres to host cells by aggregation substance and surface adhesins. ${ }^{5}$ The proton pump in E. faecalis provides an additional means of $\mathrm{pH}$ homeostasis. ${ }^{22}$ It enters a viable but noncultivable state, which helps it to survive in harsh conditions or environmental stress. $^{23}$

Among the yeast species, C. albicans is the most commonly isolated and is more commonly found in root canals with failed endodontic treatment. ${ }^{6,24}$ Though few studies have shown the presence of $C$. albicans in root canals, their role in establishing and/or progression of endodontic infection is still uncertain. ${ }^{25}$ Waltimo et al ${ }^{26}$ observed that C. albicans was highly resistant to the most commonly used intracanal medicament, calcium hydroxide. Radcliffe et $\mathrm{al}^{27}$ showed that E. faecalis was highly resistant to $\mathrm{NaOCl}$. The increasing resistance of these microbes to contemporary antimicrobials reinforces the need to explore newer materials, which could effectively eradicate them from the root canal.

In this study, $4 \% \mathrm{NaOCl}$ was effective against both the microbes and showed the highest ZOI. These results are supported by several other previous studies. ${ }^{16,26} \mathrm{NaOCl}$ exerts its antimicrobial action by saponification, chloramination, and denaturation of bacterial proteins. ${ }^{28}$ Waltimo et $\mathrm{al}^{6}$ inferred that eradication of C. albicans from the root canal under clinical conditions was an achievable goal with the routine disinfection protocol using $\mathrm{NaOCl}$, iodine compounds, or chlorhexidine. In a study by Radcliffe et $\mathrm{al}^{27} \mathrm{C}$. albicans proved highly susceptible to the action 
of $\mathrm{NaOCl}$, whereas E. faecalis was found to be resistant. While lesser concentration $(0.5 \% \mathrm{NaOCl})$ required long contact times of up to 30 minutes to achieve zero viable counts for E. faecalis, the same was achieved in 2 minutes with a higher concentration $(5.25 \% \mathrm{NaOCl})$. But, such higher concentrations are associated with cytotoxicity. ${ }^{12}$

When $\mathrm{NaOCl}$ is extruded beyond the apex, it causes chemical burns leading to localized or extensive tissue necrosis. It results in acute inflammatory reactions, which lead to swelling associated with bleeding into interstitial tissues, bruising and ecchymosis of the surrounding mucosa. When $\mathrm{NaOCl}$ comes in contact with the nerve, neurological complications like paresthesia ensue. ${ }^{29}$ The most life-threatening complication of $\mathrm{NaOCl}$ is upper airway obstruction, when $\mathrm{NaOCl}$ leaks into the oral cavity leading to ingestion or inhalation by the patient. ${ }^{30}$ Another drawback of $\mathrm{NaOCl}$ is that it oxidizes the root dentin substrate, thereby inhibiting polymerization of resin sealers used subsequently during obturation of root canal. This results in reduced bond strength of resin sealers to $\mathrm{NaOCl}$ treated dentin. ${ }^{31,32}$

There has been an increase in the use of herbal medicines over the last 15 to 20 years as they are easily available, inexpensive, lack microbial resistance, and have no adverse effects. ${ }^{33,34}$ Hence, bamboo salt, a natural herbal medicine, was selected for the study. The results of the present study showed that $5 \%$ bamboo salt was equally effective as $4 \% \mathrm{NaOCl}$ against $E$. faecalis and next best to $4 \% \mathrm{NaOCl}$ against $C$. albicans. Bamboo salt causes hypersomatic shock to the microbes by reducing the water content in the microbial cell. In addition, it has metals like $\mathrm{Zn}, \mathrm{Mn}, \mathrm{Ca}, \mathrm{P}, \mathrm{K}, \mathrm{Mg}$, and Fe, which further boost its antimicrobial property. ${ }^{20}$ These metals cause discrete and distinct injuries to microbial cells resulting in oxidative stress, protein dysfunction, and membrane damage. ${ }^{35}$ This might be the reason for the antimicrobial activity of bamboo salt. The results of the present study are in accordance with previous studies by Shin et $\mathrm{al}^{19}$ and Moon et al. ${ }^{20}$ Shin et $\mathrm{al}^{19}$ showed that $1 \%$ bamboo salt was effective against $S$. mutans and Moon et $\mathrm{al}^{20}$ observed that $5 \%$ bamboo salt caused complete inhibition of $S$. enteritidis. This is a preliminary study to assess the antimicrobial effect of bamboo salt against E. faecalis and C. albicans. Further studies using increasing concentrations of bamboo salt are required to explore its antimicrobial potential and subsequent use in dentistry.

\section{CONCLUSION}

From the results of this in vitro study, it can be concluded that $4 \% \mathrm{NaOCl}$ proved to be the most effective antimicrobial agent against both the species; $5 \%$ bamboo salt was as effective as $4 \% \mathrm{NaOCl}$ against $E$. faecalis, but significantly less effective against $C$. albicans.

\section{REFERENCES}

1. Kakehashi S, Stanley HR, Fitzgerald RJ. The effects of surgical exposures of dental pulps in germ-free and conventional laboratory rats. Oral Surg Oral Med Oral Pathol 1965 Sep;20: 340-349.

2. Sundquist, G. Bacteriological studies of necrotic dental pulps. Umeå: Department of Oral Microbiology, University of Umeå; 1976.

3. Sundqvist G, Figdor D, Persson S, Sjögren U. Microbiologic analysis of teeth with failed endodontic treatment and the outcome of conservative re-treatment. Oral Surg Oral Med Oral Pathol Oral Radiol Endod 1998 Jan;85(1):86-93.

4. Sherman JM. The streptococci. Bacteriol Rev 1937 Dec;1(1): 3-97.

5. Kayaoglu G, Ørstavik D. Virulence factors of Enterococcus faecalis: relationship to endodontic disease. Crit Rev Oral Biol Med 2004 Sep;15(5):308-320.

6. Waltimo TMT, Haapasalo M, Zehnder M, Meyer J. Clinical aspects related to endodontic yeast infections. Endod Top 2004 Nov;9(1):66-78.

7. Chandra SS, Miglani R, Srinivasan MR, Indira R. Antifungal efficacy of $5.25 \%$ sodium hypochlorite, $2 \%$ chlorhexidine gluconate, and 17\% EDTA with and without an antifungal agent. J Endod 2010 Apr;36(4):675-678.

8. Zehnder M. Root canal irrigants. J Endod 2006 May;32(5): 389-398.

9. Neglia R, Ardizzoni A, Giardino L, Ambu E, Grazi S, Calignano S, Rimoldi C, Righi E, Blasi E. Comparative in vitro and ex vivo studies on the bactericidal activity of Tetraclean, a new generation endodontic irrigant, and sodium hypochlorite. New Microbiol 2008 Jan;31(1):57-65.

10. Spencer HR, Ike V, Brennan PA. Review: the use of sodium hypochlorite in endodontics-potential complications and their management. Br Dent J 2007 May;202:555-559.

11. Sabala CL, Powell SE. Sodium hypochlorite injection into periapical tissues. J Endod 1989 Oct;15(10):490-492.

12. Hülsmann $M$, Hahn W. Complications during root canal irrigation - literature review and case reports. Int Endod J 2000 May;33(3):186-193.

13. Mehra P, Clancy C, Wu J. Formation of a facial hematoma during endodontic therapy. J Am Dent Assoc 2000 Jan;131(1): 67-71.

14. Mohammadi $Z$, Abbott PV. The properties and applications of chlorhexidine in endodontics. Int Endod J 2009 Apr;42(4): 288-302.

15. Dutta A, Kundabala M. Comparative anti-microbial efficacy of Azadirachta indica irrigant with standard endodontic irrigants: a preliminary study. J Conserv Dent 2014 Mar;17(2): 133-137.

16. Karkare SR, Ahire NP, Khedkar SU. Comparative evaluation of antimicrobial activity of hydroalcoholic extract of Aloe vera, garlic, and 5\% sodium hypochlorite as root canal irrigants against Enterococcus faecalis: an in vitro study. J Indian Soc Pedod Prev Dent 2015 Oct-Dec;33(4):274-278.

17. Zhao X, Deng X, Park KY, Qiu L, Pang L. Purple bamboo salt has anticancer activity in TCA8113 cells in vitro and preventive effects on buccal mucosa cancer in mice in vivo. Exp Ther Med 2013 Feb;5(2):549-554.

18. Lee HJ, Choi CH. Anti-inflammatory effects of bamboo salt and sodium fluoride in human gingival fibroblasts - an in vitro study. Kaohsiung J Med Sci 2015 Jun;31(6):303-308. 
19. Shin HY, You HH, Shin TY, Kim HM, You YO. Effect of Bamboo salt-pro on carries-inducing properties of Streptococcus mutans. Orient Pharm Exp Med 2003;3(1):40-45.

20. Moon JH, Shin HA, Rha YA, Om AS. The intrinsic antimicrobial activity of bamboo salt against Salmonella enteritidis. Mol Cell Toxicol 2009;5(4):324-327.

21. Heath $\mathrm{CH}$, Blackmore TK, Gordon DL. Emerging resistance in Enterococcus spp. Med J Aust 1996 Jan;164(2):116-120.

22. Evans M, Davies JK, Sundqvist G, Figdor D. Mechanisms involved in the resistance of Enterococcus faecalis to calcium hydroxide. Int Endod J 2002 Mar;35(3):221-228.

23. Lleò MM, Bonato B, Tafi MC, Signoretto C, Boaretti M, Canepari $\mathrm{P}$. Resuscitation rate in different enterococcal species in the viable but non-culturable state. J Appl Microbiol 2001 Dec;91(6):1095-1102.

24. Nair PNR, Sjögren U, Krey G, Kahnberg KE, Sundqvist G. Intraradicular bacteria and fungi in root-filled, asymptomatic human teeth with therapy-resistant periapical lesions: a longterm light and electron microscopic follow-up study. J Endod 1990 Dec;16(12):580-588.

25. Waltimo T, Kuusinen $M$, Järvensivu A, Nyberg P, Väänänen A, Richardson M, Salo T, Tjäderhane L. Examination on Candida spp. in refractory periapical granulomas. Int Endod J 2003 Sep;36(9):643-647.

26. Waltimo TM, Orstavik D, Sirén EK, Haapasalo MP. In vitro susceptibility of Candida albicans to four disinfectants and their combinations. Int Endod J 1999 Nov;32(6):421-429.

27. Radcliffe CE, Potouridou L, Qureshi R, Habahbeh N, Qualtrough A, Worthington H, Drucker DB. Antimicrobial activity of varying concentrations of sodium hypochlorite on the endodontic microorganisms Actinomyces israelli, A. naeslundii,
Candida albicans and Enterococcus faecalis. Int Endod J 2004 Jul;37(7):438-446.

28. Estrela C, Estrela CRA, Barbin EL, Spanó JCE, Marchesan MA, Pécora JD. Mechanism of action of sodium hypochlorite. Braz Dent J 2002 Jan;13(2):113-117.

29. Witton R, Henthorn K, Ethunandan M, Harmer S, Brennan PA. Neurological complications following extrusion of sodium hypochlorite solution during root canal treatment. Int Endod J 2005 Nov;38(11):843-848.

30. Becking AG. Complications in the use of sodium hypochlorite during endodontic treatment: report of three cases. Oral Surg Oral Med Oral Pathol 1991 Mar;71(3):346-348.

31. Nassar M, Awawdeh L, Jamleh A, Sadr A, Tagami J. Adhesion of Epiphany self-etch sealer to dentin treated with intracanal irrigating solutions. J Endod 2011 Feb;37(2):228-230.

32. Bueno CE, Pelegrine RA, Silveira CF, Bueno VC, Alves Vde O, Cunha RS, Pereira GD, Paulillo LA. The impact of endodontic irrigating solutions on the push-out shear bond strength of glass fiber posts luted with resin cements. Gen Dent 2016 Jan-Feb;64(1):26-30.

33. Little JW. Complementary and alternative medicine: impact on dentistry. Oral Surg Oral Med Oral Pathol Oral Radiol Endod 2004 Aug;98(2):137-145.

34. Prabhakar J, Senthilkumar M, Priya MS, Mahalakshmi K, Sehgal PK, Sukumaran VG. Evaluation of antimicrobial efficacy of herbal alternatives (Triphala and green tea polyphenols), MTAD, and 5\% sodium hypochlorite against Enterococcus faecalis biofilm formed on tooth substrate: an in vitro study. J Endod 2010 Jan;36(1):83-86.

35. Lemire JA, Harrison JJ, Turner RJ. Antimicrobial activity of metals: mechanisms, molecular targets and applications. Nature Rev Microbiol 2013 May;11:371-384. 